Volume 12

Issue 2 Images And Collective Violence:

Function, Use And Memory

$10-2018$

\title{
Book Review: Probing the Ethics of Holocaust Culture
}

Nanar Khamo

University of California, Los Angeles

Follow this and additional works at: https://digitalcommons.usf.edu/gsp

\section{Recommended Citation}

Khamo, Nanar (2018) "Book Review: Probing the Ethics of Holocaust Culture," Genocide Studies and Prevention: An International Journal: Vol. 12: Iss. 2: 200-202.

DOI:

https://doi.org/10.5038/1911-9933.12.2.1591

Available at: https://digitalcommons.usf.edu/gsp/vol12/iss2/18

This Book Review is brought to you for free and open access by the Open Access Journals at Digital Commons @ University of South Florida. It has been accepted for inclusion in Genocide Studies and Prevention: An International Journal by an authorized editor of Digital Commons @ University of South Florida. For more information, please contact digitalcommons@usf.edu. 


\title{
Book Review: Probing the Ethics of Holocaust Culture
}

\author{
Nanar Khamo \\ University of California, Los Angeles \\ Los Angeles, California, USA
}

Probing the Ethics of Holocaust Culture

Edited by Claudio Fogu, Wulf Kansteiner, and Todd Presner

Cambridge, Harvard University Press, 2016

528 Pages; Price $\$ 45.00$

Reviewed by Nanar Khamo

University of California, Los Angeles

In 1990, UCLA hosted a conference entitled "Probing the Limits of Holocaust Representation," where scholars analyzed questions of postmodern historiography in conjunction with the Holocaust, propelled by the controversial arguments articulated by Hayden White. The ensuing volume (1992), edited by Saul Friedländer, published the proceedings of the 1990 conference. In 2016, UCLA hosted a second conference entitled "Probing the Ethics of Holocaust Culture," leading to the present volume-edited by Claudio Fogu, Wulf Kansteiner, and Todd Presnerwhich is "not a sequel to the original one, but perhaps a bookend as it attempts to take stock of the salient forms of representation and the critical debates that have emerged in Holocaust studies in the intervening twenty-five years." ${ }^{11}$ References to the first conference abound in the volume. In many ways, Friedländer and White are at the heart of the collection, as a variety of scholars from different disciplines respond to the contentions raised by the two scholars with regards to the ways in which one can represent the Holocaust. The root of the original conference and collection, as well as the driving force behind the dialogue that has continued in the years that followed, is White's contention that modernist historiography employs literary techniques to represent the history of the Holocaust. To explore these questions of narrative and historiography, the editors divide the volume into five main components: the introduction, three main sections, and a concluding interview with Friedländer.

In their introduction, Kansteiner and Presner examine the field and explain how they adapted the original framework to interrogate the ethics of representing what has become a global Holocaust culture. Whereas the question of narrative, framed around Jean-François Lyotard's differend, with regards to historiography remains imperative, new advances in the field require a shift in its approaches. One of major changes is the proliferation of digital archives through technological advances. The introduction details a historical look at the field of Holocaust studies, a summary that could also be useful as a pedagogical tool to introduce students to the field, as well to consider questions of literary techniques and historiography.

The editors preface each of the three main parts, which are divided thematically, by introducing the articles where they consider the overarching argument of each section, as well as the stakes of the proposed arguments. The first part, entitled "The Stakes of Narrative" further explores the driving questions of narrative and historiography. White engages with a close reading of the literary techniques employed in Friedländer's two volumes of Nazi Germany and the Jews to argue that the text is an example of modernist historiography, followed by Friendländer's dissenting response. ${ }^{2}$ Kansteiner and Ann Rigney continue to interrogate the questions of narrative in representing the Holocaust in their articles, followed by a response by Christopher R. Browning and an interview

\footnotetext{
${ }^{1}$ Wulf Kansteiner and Todd Presner, "Introduction: The Field of Holocaust Studies and the Emergence of Global Holocaust Culture," in Probing the Limits of Holocaust Culture, ed. Fogu et al. (Cambridge: Harvard University Press, 2016), 1.

${ }^{2}$ Saul Friedländer, Nazi Germany and the Jews, 1939-1945: The Years of Extermination (New York: Harper Perennial, 2008); Saul Friedländer, Nazi Germany and the Jews: Volume 1: The Years of Persecution: 1933-1939 (New York: Harper Perennial, 1998); Saul Friedländer, Probing the Limits of Representation: Nazism and the "final Solution" (Cambridge: Harvard University Press, 1992).
} 
with Daniel Mendelsohn, respectively. The first part introduces what is a defining characteristic of this volume: the use of responses and interviews.

The second part of the collection, entitled "Remediations of the Archive" examines new issues with regards to Holocaust culture, in comparison to the original 1990 conference, as a result of technological advances, raising ethical questions about global Holocaust culture. The articles in this section interrogate the question of the archive, both that of the victim and that of the perpetrator, as well as a spatial shift in Holocaust studies. Presner's article explores the largest database of Holocaust testimony, the Shoah Foundation's Visual History Archives (VHA), to argue that "distant listening" (his rearticulated use of Franco Moretti's concept of "distant reading") "is ethical precisely because it takes into account the metadata (specifically, the keywords linked to testimony segments) of every survivor who had his or her story recorded in the VHA." ${ }^{3}$ To consider the possibility of a spatial turn in Holocaust Studies, Fogu discusses the 2009 Geographies of the Holocaust project where a group of geographers represent visual evidence of the Holocaust, which they further delineate in an interview following the article. ${ }^{4}$ Questions of cinema and architecture follow, with Gavriel D. Rosenfield's consideration of the relationship between "art and atrocity" in Peter Eisenman's design of the Memorial to the Murdered Jews of Europe in Berlin. ${ }^{5}$ Eisenman responds to Rosenfield's analysis in a short essay to further discuss the concept of deconstructivism and the way it does not accurately define his approach to the construction of the monument. This section exemplifies the shifting winds of the field as new technologies shape the ways in which scholars understand not only the concept of the archive, but also the nature of what constitutes evidence.

The third section, entitled "The Politics of Exceptionality," is where, under the framework of Holocaust uniqueness, questions of the Holocaust, colonialism, and comparative genocide studies come to a head. Omer Bartov discusses the difficulty of linking the Holocaust with other genocides, referencing, for example, the inability to link the genocide committed by the Germans in SouthWest Africa against the Herero and Nama populations with the Holocaust. Dirk Moses interrogates Bartov's anxieties as a point of departure and adds his own concerns about the politicization of the fields of Holocaust and genocide studies. Michael Rothberg contributes to the discussion by expounding upon his vision of multidirectional memory, noting in the original volume "the absence of a cosmopolitan perspective focusing on human rights. ${ }^{\prime 6}$ Rothberg traces the biography of Marceline Lordian-Ivens as an example of what he calls "Holocaust intersectionalism," showing the ways in which this collection proposes an inclusive history of violence as the future of Holocaust studies. ${ }^{7}$ Judith Butler and Elisabeth Weber continue analyzing questions of narrative in a multidirectional framework. This section illustrates the tensions currently within Holocaust studies, namely the idea of the singularity of the event in relation to other events. The questions of colonialism, imperialism, and the Holocaust continue to remain contentious, particularly as the fields of Holocaust and genocide studies are linked, yet distinct. Further articulating the distinction between the two fields remains the task of future tomes.

The volume concludes with an interview with Friedländer conducted by the three editors. Friedländer recalls the inception of the initial conference, as well as discusses the past, present, and future of Holocaust studies. In reading the interview, one cannot help but wish for the inclusion of White's voice, particularly as the editors interrogate Friedländer about White's contentions with regards to narrative tools. Ending with an interview seems appropriate for a volume that

\footnotetext{
${ }^{3}$ Todd Presner, "The Ethics of the Algorithm: Close and Distant Listening to the Shoah Foundation Visual History Archive," in Probing the Limits of Holocaust Culture, ed. Fogu et al. (Cambridge: Harvard University Press, 2016$), 199$.

${ }^{4}$ Anne Kelly Knowles, Tim Cole and Alberto Giordano, eds. Geographies of the Holocaust (Bloomington: Indiana University Press, 2014).

${ }^{5}$ Gavriel De. Rosenfeld, “Deconstructivism and the Holocaust: Peter Eisenman's Memorial to the Murdered Jews of Europe," in Probing the Limits of Holocaust Culture, ed. Fogu et al. (Cambridge: Harvard University Press, 2016$), 284$.

${ }^{6}$ Michael Rothberg, “The Witness as 'World' Traveler: Multidirectional Memory and Holocaust Internationalism before Human Rights," in Probing the Limits of Holocaust Culture, ed. Fogu et al. (Cambridge: Harvard University Press, 2016), 357.

${ }^{7}$ Ibid., 359
} 
made strong use of them throughout the text to foster an interdisciplinary dialogue that allowed academics and artists the opportunity to weigh in on various issues of representation, ethics, and archives.

Overall, this volume offers a robust, rich collection of articles by leading scholars whose goals are to assess the state of the field of Holocaust studies. As noted, the works are often in response to one another, with references to the other articles published in the collection, creating an unusually interconnected volume. This gives the reader the impression of an on-going dialogue, rather than a simple collection of essays that are loosely linked by a theme. The essays will be useful sources of knowledge to scholars interested in the fields of Holocaust, genocide, trauma, and memory studies, as well as academics interested in questions of narrative, history, imagination, and historiography. The collection provides an overview of how the field of Holocaust studies has changed and evolved over the years, and its on-going disciplinary tensions and anxieties. Even as the Holocaust is the subject of this volume, the questions that the scholars probe point to the very essence of history and literature to consider the ways in which literary techniques represent violent historical events. In that vein, scholars interested in larger questions of the state of the humanities and the social sciences might find compelling insights pointing to the future possibilities of these academic disciplines. 